\title{
PENGEMBANGAN PRODUK SEMIR SEPATU DENGAN PEMANFAATAN LIMBAH KULIT PISANG KEPOK (Musa Paradisiaca L.)
}

\author{
Andi Haslindah ${ }^{1}$, Andrie $^{2}$, Dian Pratiwi Efendi ${ }^{3}$ \\ ${ }^{1,2,3}$ Program Studi Teknik Industri, Fakultas Teknik, Universitas Islam Makassar \\ Jl. Perintis Kemerdekaan km.9 No. 29 Makassar, Indonesia 90245 \\ Email: andihaslindah.dty@uim-makassar.ac.id, dianpratiwiefendi@gmail.com
}

\begin{abstract}
ABSTRAK
Kota makassar yang terkenal dengan kuliner olahan buah pisang yang dapat menghasilkan limbah organik, memanfaatkan limbah kulit pisang sisa olahan kuliner agar dapat digunakan dengan baik dan meminimalisir sampah organik yang ada di lingkungan sekitar dengan membuat semir sepatu dari bahan baku limbah kulit pisang. Tujuan penelitian ini untuk mengetahui bagaimana proses pembuatan dan pengembangan pemanfaatan produk semir sepatu dari limbah kulit pisang. Dengan menggunakan metode destruksi kering (Pengabuan) untuk proses pembuatan semir sepatu dimulai dari pengumpulan bahan baku dengan mengeringkan kulit pisang lalu mengukur semua bahan yang akan digunakan dalam proses pembuatan semir sampai dengan hasil produk menjadi semir sepatu, metode regresi linear berganda digunakan untuk mengetahui korelasi responden terhadap tanggapan penggunaan semir sepatu dari bahan baku limbah kulit pisang. Hasil dari penelitian ini memperoleh produk semir sepatu berbahan alami dengan teksture yang padat, tidak lengket, tidak beraroma menyengat dan tidak menimbulkan iritasi pada kulit manusia. Hasil pengaplikasian semir sepatu digunakan pada bahan sepatu kulit asli dan kulit sintetis. Hasil dari penggunaan produk menghasilkan sepatu yang mengkilap dan produk tidak menimbulkan iritasi pada kulit Sepatu mengkilap, teksture semir sepatu padat, respon terhadap kulit manusia tidak menimbulkan alergi atau iritasi pada kulit.
\end{abstract}

Kata kunci:Limbah, Kulit Pisang, Semir Sepatu

\begin{abstract}
The city of Makassar is famous for its processed banana culinary which can produce organic waste, utilizing the residual processed banana peel waste so that it can be used properly and minimize organic waste in the surrounding environment by making shoe polish from banana peel waste raw material. The purpose of this study was to determine how the process of making and developing the use of shoe polish products from banana skin waste. By using the method of dry destruction (ashing) for the process of making shoe polish, it starts from collecting raw materials by drying the banana peels and then measuring all the materials that will be used in the process of making polish to the product results into shoe polish. Multiple linear regression method is used to determine the correlation of respondents to the response of the use of shoe polish from banana peel waste raw material. The results of this study obtained a shoe polish product made from natural with a dense texture, not sticky, no scent and does not cause irritation to human skin. The results of the application of shoe polish are used in genuine leather shoes and synthetic leather. The results of using the product produce shiny shoes and the product does not cause irritation to the skin. Shiny shoes, solid shoe polish texture, the response to human skin does not cause allergies or irritation to the skin
\end{abstract}

Keywords : Waste, Banana Peel, Shoe Polish 


\section{PENDAHULUAN}

Indonesia adalah Negara agrikultur yang kaya akan sumber daya alam khususnya dibidang pertanian dan perkebunan. Tak heran jika Indonesia menghasilkan macam - macam produksi dari limbah sampah seperti ampas padi, jerami, dan serbuk gergaji dari sektor pertanian. Dan dari sektor perkebunan dapat menghasilkan tempurung kelapa sawit, biji alpukat, dan kulit buah pisang (Andani Amelia, 2015).

Memanfaatkan segala jenis limbah untuk mengurangi masalah lingkungan telah menjadi perhatian masyarakat pada umumnya. Kota Makassar juga terkenal dengan kuliner olahan dari berbagai jenis buah dan khususnya pada buah pisang tidak heran jika hampir disepanjang ruas jalan dan sudut kota makassar ini kita akan menemui kelompok pedagang gorengan kaki limadan pedagang pisang epe' yang terletak dipantai losari.

Selain menjadi limbah atau untuk pakan ternak kulit pisang juga dapat kita manfaatkan sebagai bahan baku semir sepatu yang lebih sehat, produk semir sepatu pada umumnya $80 \%$ terdiri dari bahan kimia yang tidak aman terhadap kesehatan manusia, mulai dari gangguan pernapasan dan iritasi kulit ketika tidak sengaja terkena kulit manusia pada pengaplikasian semir sepatu.

Tujuan penelitian ini untuk mengetahui bagaimana proses pembuatan dan pengembangan pemanfaatan produk semir sepatu dari limbah kulit pisang. Dalam proses pembuatan semir sepatu dari bahan baku limbah kulit pisang, terdapat beberapa hasil penelitian sebelumnya yang dilakukan dengan menggunakan bahan baku kulit pisang yaitu pemanfaatan kulit pisang (Musa Paradisace) dalam pembuatan semir sepatu oleh Hari Anna Sari (2018), Kulit Pisang Sebagai Semir Sepatu oleh (Alifani Bima A.P, dkk (2015).

\section{METODE PENELITIAN}

Jenis data yang digunakan yaitu data kualitatif dan kuantitatif. Sumber data pada penelitian ini yaitu hasil observasi langsung untuk memilih jenis pisang yang menjadi bahan baku pembuatan produk semir sepatu dari limbah kulit pisang kepok dan menyebar kuesioner untuk mengetahui respon pengguna.

\section{Alat, Bahan dan Metode :}

Alat yang digunakan dalam penelitian ini adalah gelas kimia, spatula, hot plate, pengayak, termometer, statif dan klem, wadah plastik, magnetik stirrer, blender, oven tanur, filler, batang pengaduk, pipet ukur, dan neraca analitik sebagai alat dalam proses pembuatan bahan baku semir sepatu dari limbah kulit pisang kepok. Laptop dan kamera dengan mengunakan microsoft word 2010 sebagai alat mengolah data-data yang diperoleh dalam penelitian ini.

Bahan yang digunakan dalam penelitian ini adalah kulit pisang dari pedagang kaki lima dan pedagang pisang epe'. Menggunakan ukuran skala kecil yang ditentukan oleh peneliti yaitu kulit pisang yang telah di dekstruksi kering sebanyak 10gr, alkohol 95\% 10ml, vaseline 5gr, dalam penelitian ini metode yang digunakan yaitu dekstruksi kering dan regresi linear berganda.

Metode yang digunakan dalam penelitian ini yaitu metode destruksi kering oleh Susila Kristianingrum, (2012). Untuk bagian dari tahap pembuatan produk hingga menjadi semir sepatu dari bahan baku limbah kulit pisang kepok. Dan metode regresi linear berganda untuk mengetahui korelasi dari setiap butir pertanyaan kuesioner terhadap responden.

\section{HASIL DAN PEMBAHASAN:}

\section{Pembuatan}


Pembuatan produk semir sepatu berbahan baku limbah kulit pisang kepok (musa paradisiaca L.). Mengumpulkan bahan baku, memilah, menimbang, mencacah dan mengeringkan kulit pisang dengan proses dekstruksi kering merupakan suatu metode perlakuan awal yang bertujuan untuk menguraikan zat organik pada sampel kulit pisang yang melepas senyawa lain yaitu pelepasan molekul air $\mathrm{H}_{2} \mathrm{O}$, hasil yang didapatkan setelah didestruksi adalah kulit pisang berubah warna menjadi warna hitam, karna adanya proses pembakaran yang tidak sempurna dengan mengahsilkan $\mathrm{C}, \mathrm{CO}, \mathrm{H}_{2} \mathrm{O}$, pada tahap ini bahan organik yang terkandung pada kulit pisang akan di degradasi menjadi karbon dan senyawa non organik akan diubah menjadi senyawa tar. Reaksi yang terjadi pada saat proses dekstruksi adalah:

$$
\mathrm{C}_{6} \mathrm{H}_{12} \mathrm{O}_{6}+\mathrm{O}_{2} \longrightarrow 4 \mathrm{C}_{(\mathrm{s})}+2 \mathrm{CO}_{(\mathrm{g})}+6 \mathrm{H}_{2} \mathrm{O}_{(\mathrm{g})}
$$

Berdasarkan tahap pembuatan bahan baku dari limbah kulit pisang yang siap untuk di olah menjadi sebuah produk semir sepatu berbahan alami dengan percobaan skala kecil dan komponen hasil dari percobaan yang telah dilakukan yaitu sebagai berikut:

Tabel 1 Komponen Produk

\begin{tabular}{|c|l|l|lr|}
\hline No & $\begin{array}{l}\text { Nama } \\
\text { Komponen }\end{array}$ & jumlah & Keterangan \\
\hline 1 & $\begin{array}{l}\text { Kulit Pisang } \\
\text { Kepok (Musa } \\
\text { Paradisiaca L.) }\end{array}$ & $10 \mathrm{gr}$ & $\begin{array}{l}\text { Sebagai } \\
\text { baku bahan } \\
\text { pembuatan } \\
\text { sepatu }\end{array}$ & $\begin{array}{r}\text { untuk } \\
\text { semir }\end{array}$ \\
\hline 2 & $\begin{array}{l}\text { Alkohol } \\
\text { (Alcohol) }\end{array}$ & $30 \mathrm{ml}$ & $\begin{array}{l}\text { Sebagai } \\
\text { pelarut }\end{array}$ & bahan \\
\hline 3 & $\begin{array}{l}\text { Vaseline } \\
\text { (Petrolatum) }\end{array}$ & $5 \mathrm{gr}$ & $\begin{array}{l}\text { Sebagai } \\
\text { pengawet, }\end{array}$ & $\begin{array}{r}\text { bahti } \\
\text { jamur, } \\
\text { pelembab } \\
\text { dan } \\
\text { kulit sepatu }\end{array}$ \\
\hline
\end{tabular}

Sumber:data diolah penulis, 2019

Selanjutnya pengukuran bahan baku dan bahan lainnya menggunakan neraca analitik, mengukur alkohol menggunakan pipet tes, proses selanjutnya memanaskan semua bahan yang telah dicampur kedalam gelas kimia menggunakan hotplate dengan suhu $65^{\circ} \mathrm{C}$, diaduk menggunakan

batang pengaduk dan magnet stirrer dengan jangka waktu pembuatan selama 30 menit. Berdasarkan hasil percobaan yang dilakukan memperoleh produk semir sepatu berbahan alami dengan teksture yang padat, tidak lengket, tidak beraroma menyengat dan tidak menimbulkan iritasi pada kulit manusia Sedangkan, pada penelitian sebelumnya yang dilakukan oleh Henydria Adiningtyas (2012) dengan menggunakan batok kelapa bahwa Kualitas semir sepatu batok kelapa memiliki keunggulan pada daya kilap dan warna dan Hari anna sari (2018) Dengan menggunakan kulit pisang kita dapat mengurangi pemakaian semir sepatu yang bahannya tidak alami yang lama kelamaan akan mengurangi kualitas dari sepatu

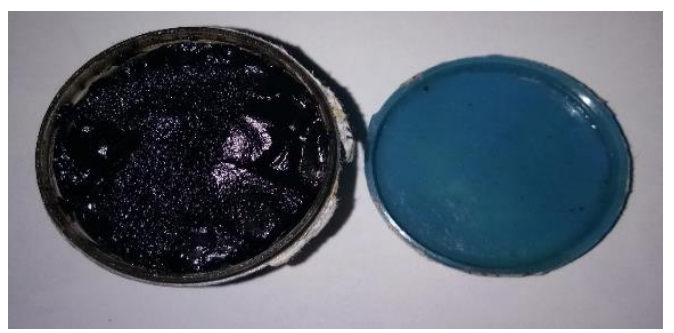

itu dan selain itu dengan mengguanakan kulit pisang kita bisa mengurangi biaya yang harus dikeluarkan untuk membeli semir sepatu.

Gambar 1 Hasil Produk

\section{Pengembangan}

Data kuesioner adalah data yang diperoleh dari penyebaran kuesioner kepada responden yang akan menggunakan sampel penelitian produk semir sepatu berbahan bau limbah kulit pisang. Data yang diperoleh dari kuesioner dibagi dalam beberapa klarifikasi yaitu jenis kelamin, jenis usia, dan jenis pendidikan. Diberikan butir pertanyaan responden. 


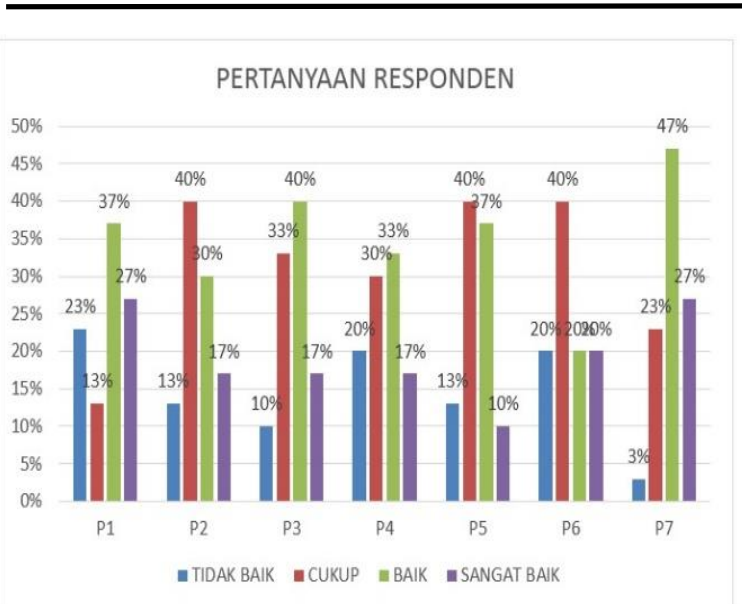

Sumber: Data diolah oleh peneliti. 2019

Gambar 2 Data Kuesioner

Berdasarkan gambar 2 total rata-rata dari presentasi jawaban responden semir sepatu pada umumnya adalah bagian dari kebutuhan masyarakat dari 30 responden sebanyak 37\% dari jumlah rata-rata menjawab baik. Sedangkan untuk hasil semir sepatu dari limbah kulit pisang sebanyak $47 \%$ menilai produk ini layak untuk diproduksi. Melihat dari sisi bahan yang mudah didapatkan, murah, baik untuk kesehatan dan dapat membantu meminimalisir salah satu sampah organik.

Menurut Acmad Kurniawan (2017) bahwa pengujian hipotesis dilakukan menggunakan metode regresi linear berganda, bahwa diperoleh variabel independen yang berpengaruh secara signifikan terhadap hasil semir sepatu limbah kulit pisang yaitu variabel teksture semir sepatu dengan tingkat signifikansi 0,673>0,05.

\section{KESIMPULAN:}

Berdasarkan latar belakang rumusan masalah dan analisis data pembahasan hasil penelitian maka penelitian terhadap pembuatan produk semir sepatu berbahan baku limbah kulit pisang, menghasilkan kesimpulan sebagai berikut :

1. Pembuatan produk semir sepatu berbahan baku limbah kulit pisang dengan menggunakan metode destruksi kering menghasilkan produk semir sepatu berbahan alami dengan teksture yang padat, tidak lengket, tidak beraroma menyengat dan tidak menimbulkan iritasi pada kulit manusia

2. Pengembangan Pemanfaatan produk semir sepatu dari limbah kulit pisang dengan menambahkan variabel vaseline sebagai bahan pengganti asam cuka dari peneliti sebelumnya.

\section{UCAPAN TERIMA KASIH:}

Terima kasih kepada Kepala Lab dan Asissten Lab Universitas Haluoleo Kendari, para dosen pembimbing penguji, dan teman-teman yang selalu memberikan arahan dan masukannya sampai terselesainya penelitian ini. Terima kasih juga kepada kedua orang tua kami yang selalu memberikan dorongan serta dukungan secara moral maupun moril.

\section{DAFTAR PUSTAKA:}

Achmad Kurniawan, 2017. Analisis pengaruh harga, kualitas, pelayanan terhadap pemilihan lapangan futsal dengan menggunakan metode regresi linear berganda, Skripsi STIMIK Nusa Mandiri Jakarta.

Ahmad Hanafie, Musrawati, Asti, (2018),Analisis Strategi Pengembangan Produksi Gula Merah Cair pada IKM Gula Merah Cair dengan Menggunakan Metode QFD, Volume 12, Nomor 24, Oktober 2017, hal. 1747 1750, Fakultas Terknik Univ. Islam Makassar.

Andani Amelia,2015. Pemanfaatan Limbah Pisang Kepok. https://www.academia.edu/21488110/Pem anfaatan_Limbah_Kulit_Pisang. Diakses tanggal 22 Juli 2019

Alifani Bima A.P, Ardhana P, Iqbal I. 2015. Kuit Pisang Sebagai Semir Sepatu. 
Program Karya Ilmiah, Sekolah Menengah Pertama Al Hikmah Full-Day School. Surabaya

Hari Anna Sari. 2018. Pemanfaatan Kulit Pisang (Musa Paradisiace) Dalam Pembuatan Semir Sepatu, Skripsi Universitas Andalas Padang.

Henydria Adiningtyas, 2012. Pemanfaatan limbah batok kelapa menjadi semir sepatu berkualtias tinggi, program kreativitas manusia.Surabaya

https://www.academia.edu/8931720/PKM PIKMEN edit. Diakses tanggal 17 Juni 2019.

Susila, K. 2012. Kajian Berbagai Proses Dektruksi Sampel Dan Efeknya. Prosiding Seminar Nasional Penelitian. Yogyakarta: FMIPA, UNY. 